\title{
Concept of E-Government in Management of Indonesia's Village Funds
}

\author{
$1^{\text {st }}$ Andi Nur Annisa Meilany \\ Faculty of Law \\ Padjajaran University \\ Bandung, Indonesia \\ anmeilany@yahoo.com \\ $4^{\text {th }}$ Indra Perwira \\ Faculty of Law \\ Padjajaran University \\ Bandung, Indonesia
}

\author{
$2^{\text {nd }}$ Dewi Kania \\ Faculty of Law \\ Padjajaran University \\ Bandung, Indonesia
}

\author{
$3^{\text {rd }}$ Zainal Muttaqin \\ Faculty of Law \\ Padjajaran University \\ Bandung, Indonesia
}

\begin{abstract}
This research aims to make the concept of egovernment a great potential that can be utilized to meet the needs of the community in managing village funds. This concept refers to a transformation from traditional government to elective-based government to produce effective and efficient governance is a very important issue. The preparation of this research is carried out by classifying the legal fields, selecting reference books that are considered to represent material in each legal field, quoting the thoughts of experts contained in the selected reference books, and determining the keywords for each quote. The result of the study is Through the concept of e-government, creating community elements becomes important in the process of making APBDes to sharpen the substance of the APBDes as an embodiment and mandate of the people to the Village Government in improving the welfare of the people represented as "democratic subjects" and the quality of their services to the community and to prevent corruption in the use of village funds.
\end{abstract}

Keywords-Village Funds, E-Government, Village Government

\section{INTRODUCTION}

Research that specifically examines the role of egovernment in reducing the level of administrative corruption carried out in developing countries is carried out by Asorwoe (2014) showed that e-government has the potential to reduce the level of administrative corruption in public services. Researchers recommend developing countries in Sub-Saharan Africa to develop e-government as an anti-corruption tool to reduce administrative corruption and poverty, and increase economic growth. Besides at the country level, various studies on the impact of e-government on corruption are also carried out at the state and local government level. Shim and Eom (2008) in their research using national data suggest that in the United States e-government has a positive effect on consistently reducing the level of corruption at the local government level. [1]

As one of the indicators of development, controlling corruption is a problem that is commonly found in developing countries. One of the government's efforts in controlling corruption is to increase transparency and accountability both in administration and public services. With the development of Information and Communication Technology (ICT), these efforts will be carried out by integrating ICT utilization with e-government implementation. Navarra and Cornford state that egovernment influences reforms in government agencies in terms of accountability and transparency, efficiency, decentralization, and marketisation. These aspects play an important role in controlling corruption in government. Thus, by implementing e-government principles, namely increasing openness and trust in government institutions [2], e-governmnet can contribute to controlling the level of corruption which can further encourage the achievement of economic policy goals and build trust in government institutions.

Like India, to protect farmers, the International Business Division of the Indian Tobacco Company (ITCIBD) issued an e-government initiative called e-Choupal (which means a village meeting place). E-Choupal is useful not only for agricultural products but also for selling household appliances and consumer goods. Each eChoupal is equipped with a PC, internet connection, printer, and an Interrupted Power Supply (UPS). If the power supply is uncertain, a solar panel is provided, and if internet connectivity is not up to standard, then a Very Small Aperture Terminal (VSAT) connection is provided along with other solar panels to support it [3].

From the various studies above the researchers associate e-government with economic growth. By improving the quality of better governance, in this case related to governance, improved governance will have the potential to improve the economy which will continue to have an impact on development. However, the implementation of e-government will not provide optimal results without the role of the community to participate in it. So that community participation needs to be included as an additional variable in research on e-government implementation . 
One tangible form of regional autonomy is the granting of authority to each village to manage their own region, including the authority of the village head to manage finances. Based on Article 1 number 1 of Undang-Undang Nomor 6 tahun 2014 concerning Villages (hereinafter referred to as "Village Law") it is stated that: "Village is a village and a customary village or what is referred to by another name, hereinafter referred to as Village, is a legal community unit that has the authority to manage and manage government affairs, the interests of the local community based on community initiatives, rights of origin, and / or rights traditionally recognized and respected in the government system of the Unitary Republic of Indonesia".

The village is also interpreted as a legal community unit that has an original arrangement based on special original rights [4]. According to Bintarto (1989), a village is a unitary area that is inhabited by a number of families that have their own government system (headed by a Village Head) or a village is a group of houses outside the city which is a unit. In other countries they are also familiar with the Village Concept, such as barangay in the Philippines, panchayat in Indo Pakistan, sultanates in Malaysia, small kingdoms in Nepal, gamb sabbawas in Sri Lanka, and sakdina in Thailand. Name - the name on top of the political structures with specific functions that are already known and practiced so long in each community [5].

In Indonesia, one source of village income is derived from the State Budget / State Budget Allocation. The APBN allocation is one part of village financial sources that has a significant amount of income and receives special attention listed in Peraturan Pemerintah Nomor 60 Tahun 2014 tentang dana desa yang bersumber dari APBN [6]. Article 1 paragraph (2) states that village funds are funds originating from the APBN which are intended for villages that are transferred through the Regency / city Regional Revenue and Expenditure Budget and are used to finance governance, development implementation, community development, and community empowerment.

In reality, there are several obstacles that hinder the development of the village itself, these obstacles are planning to manage the village, the management of the funds the village, as well as increase the capacity of the community. The existence of Article 26 paragraph (2) letter $\mathrm{C}$ in the Village Law which gives financial management authority to the village head to manage finances and Village Assets. Authority which granted the Act Village that could potentially lead to the misuse of power by the head of the village. It is can be seen from some of the cases that have occurred, namely that there are 900 head of the village were affected by the case of abuse of Village's Fund. Furthermore in relation to the responsibility of the village head in the decision Number 187 / Pid.B /2010/PN.SKG with the defendant Sudirman, S.Pd as the former Village Head in Pajalele Village, Tamasitolo Sub-District, Wajo Regency, South Sulawesi said that Sudirman, S. Pd has been proven legally and convincingly guilty of abusing authority, opportunities, and means that harm the country's finances to the point of irresponsibility and has the purpose of benefiting oneself or another person or a corporation.

Seeing some of the cases that led the head of the relevant village authorities and responsibilities of village heads in managing finances village that is not running as it should, then it takes the concept of e-government or government electronic (official abbreviation of the phrase "electronic government" as a translation of " e -government ") which is a great potential that can be utilized to meet the needs of the community. Discussion on the transformation from traditional government to electronic-based government to produce effective and efficient governance is a very important issue.

Realizing the benefits of e-Gov, the Indonesian government has issued a National Policy and Strategy Development of Electronic Government through Inpres Nomor 3 Tahun 2003 as the legal basis for all policies in the field of Electronic Government as well as several articles in Village Law explicitly talking about Communication Information Technology (ICT) for the Village, which is about Appropriate Technology as well as Peraturan Pemerintah Republik Indonesia Nomor 82 Tahun 2012 concerning the Implementation of Electronic Systems and Transactions. But however, the rules have not been implemented with good.

Based on the background description above, the focus of this study is to answer the issue of How are the Administrative Responsibilities of Village Heads in Using Village Funds Sourced from the State Budget? and How does the concept of e-government in managing village funds influence the Reduction of Corruption Levels?

\section{METHODS}

This research uses the Normative Juridical approach, which is research that uses data obtained through library materials. The first step undertaken by this research is based on secondary legal material which includes legal documents, official documents, books, jurisprudence relating to legal analysis. With regard to the use of normative juridical approaches, this research is conducted through the study of library data carried out on data secondary. Data collection techniques in this writing through library research, namely to study and analyze systematically the laws and regulations, jurisprudence, books, legal journals, papers and other state regulations relating to the discussion of the material [6].

\section{RESULTS AND DISCUSSION}

The responsibility of the Village Head in Using Village Funds Sourced from the State Budget and Expenditures is very large. Moreover in context of the village administration, village finance is a major asset for the village to be able to realize prosperity and in rural development. so that success or failure of the village is in the main role of the village head. this is as in the village law in Article 73 and Article 74.[7]

The village head as an integral part of village development, holds a greater duty including responsibility to the village community than the superior government that 
gives the task and authority. As an integral part of village development, the Village Head is inseparable from the village administration as the organization where he works and performs his role. The village head becomes an important role because he is in charge of leading and mobilizing community participation in accelerating village development.[8]

The responsibility of the Head of the village in the use of the Village Fund Sourced from State Budget d nature Regulation No. 113 of 2014 states that the village Financial management is an activity that includes the overall planning, implementation, administration, reporting, and financial accountability village. In Article 2 concerning the principle of managing Village Finances, Village Finances are managed based on the principles of transparency, accountability, participation and are carried out in an orderly and budgetary discipline. [9]

The central government in granting autonomous rights to the regions in financial matters certainly expects to be able to fix the system of government which has been considered as an inefficient, slow, and ineffective bureaucracy. The stages in the financial management process as referred to in Article 93 paragraph (1) of Village Law include: 1) Planning; 2) Implementation; 3) Administration; 4) Reporting; 4) Supervision; 5) Liability.

In terms of accountability of village heads the implementation of the village government is intended as an evaluation material by the regent / mayor on the basis of guidance and supervision. Administrative Responsibility by the Village Head in Using Village Funds Sourced from the State Budget based on, not only see his responsibilities in carrying out his duties as Implementing the Village Government, but also in controlling the village apparatus.

Village Heads who violate this prohibition will be subjected to administrative sanctions in the form of verbal warnings and / or written warnings. In the event that administrative sanctions are not carried out, temporary termination actions are taken and can be continued with dismissals. So, in essence, in carrying out their duties, village officials are prohibited from abusing their authority. For those who break them, the village administration concerned may be subject to administrative sanctions.

In addition, these actions can also be categorized as corruption. For this reason, we refer to Law Number 31 of 1999 concerning Eradication of Corruption (Law 31/1999) as amended by Law Number 20 of 2001 concerning Amendment to Law Number 31 of 1999 concerning Eradication of Corruption, where there is a criminal threat for people who abuse their authority which can adversely affect state finances.

Article 3 of Law 31/1999, reads: Any person who has the purpose of benefiting himself or another person or a corporation, misusing the authority, opportunity or means available to him because of a position or position that could harm the state finances or the economy of the country, is convicted with imprisonment life imprisonment or imprisonment for a minimum of 1 (one) year and a maximum of 20 years and or a fine of at least Rp50 million and a maximum of Rp1 billion. So, if it is related to the misuse of village finances such as misuse of the Village Fund Budget, then the act can be categorized as corruption.

Good governance in the management of village funds is an important pillar not only for the administration of the government itself, but also for the sustainability of village development. Therefore, currently various assessments are carried out to assess the level of good governance in almost all countries in the world. One of the measurements carried out by the World Bank is based on Kaufman's research in the Worldwide Development Index (WDI) by establishing several indicators namely; (1) controlling corruption, (2) government effectiveness, (3) political stability and the absence of violence and terrorism, (4) regulatory quality , (5) rule of law, and (6) freedom issue opinions ( voice and accountability ). Through these measurements it can be seen that the level of corruption is an important indicator for assessing good governance. That is because the size of the impact of corruption on the economy is quite large. Corruption in government can reduce the efficiency and effectiveness of public services which will ultimately increase transaction costs, distort incentives, and damage the legal order [10].

The role of e-government has the potential to reduce the level of corruption through the types of causes of corruption in the context of individuals and the work, organization, and environment can be explained in accordance with the principles of implementation. In the context of individuals and work, e-government implementation has a big role in reducing the number of personal contacts or direct interactions between service providers and service users where the possibility of corruption occurs a lot arises from the interaction in an activity. Some examples of efforts to reduce direct interaction are applied in e-procurement or one stop services, for example in making business licenses. The reduction in the number of direct interactions can prevent the number of individuals who are likely to take action to maximize utility through corrupt actions.

Open government initiatives and implementation of egovernment in a village certainly cannot be separated from the entry of the internet into the village. This needs to create the ease of village communities in accessing village officials and articles posted on the Village website based on the characteristics of open government. First, in terms of socialization of laws and government data, the village government has regularly presented data on the Village Budget and Expenditure Budget (APBDes), the MediumTerm Village Development Plan (RPJMDes) which contains the direction of village development policies for five years, and other laws. Second, in terms of the perception of people's right to information, the village government apparatus must have an awareness of the importance of accountable governance in development. By presenting the village budget on their website, the village government realizes that the village government needs to participate in realizing transparent and accountable institutional arrangements. However, this awareness is not only limited to the obligations of village officials to their citizens, but also the desire of the village government to increase the level of government confidence above. 
Village officials see that accountable governance is not only related to the level of trust downward (to villagers), but also to the level of trust upward (to the district government and other policymakers). This is considered important because so far the village government has been seen as an incompetent government in matters that are technological and closely related to the news of corruption in village funds. Third, regarding the level of community participation, the village government should carry out their role in realizing open government by providing access to information on the village budget and the law regarding village work procedures. Fourth, regarding the mechanism of citizen complaints, the village community should be able to submit proposals using social media such as WhatsApp. However, direct meetings or face-to-face meetings remain the primary choice of residents, such as at regular RT, RW and village meetings.

\section{CONCLUSION}

The Village Head in the management of village funds must be in line with "good financial governance" which must first be considered is to form a budget that feels democratic by prioritizing elements of community participation. Failure to determine or review procedures where there are obligations to be implemented or to implement the wrong system are examples of maladministration. In addition, these actions can also be categorized as corruption.

Implementation of the concept of e-government aims to prevent the occurrence of corruption use village funds. It is due to the implementation of concept of e-government can be created an transparency and accountability both in the administration and public services. With the development of Information and Communication Technology (ICT), the effort is carried out by integrating ICT utilization with $e$ government implementation in Village Fund Management.

\section{REFERENCES}

[1] Asorwoe, E. Can E-Government Mitigate Administrative Corruption? An Empirical study into the Potential Role of EGovernment in Eradicating Administrative Corruption in SubSaharan Africa?, Florida International University: Global Institute for Research \& Education, 2014.

[2] Navarra, D., dan Cornford, T. "A Policy Making View of EGovernment Innovations in Public Governance". Information Technology in Government, 2003.

[3] Kushandajani, Implikasi Uu Nomor 6 Tahun 2014 Tentang Desa Terhadap Kewenangan Desa, Yustisia. Vol. 4 No. 2 Mei - Agustus 2015

[4] Bintaro, R. Dalam Interaksi Desa-Kota dan Permasalahannya, Ghalia Indonesia, Jakarta, 1989.

[5] Jimly Asshiddiqie, Konstitusi dan konstitusionalisme Indonesia, Sinar Grafika, Jakarta, 2010

[6] Soekanto, Soerjono dan Sri Mamuji, Penelitian Hukum Normatif (Suatu Tinjauan Singkat), Rajawali Pers, Jakarta, 2001.

[7] Vel, J., Zakaria, Y., \& Bedner, A., Law-Making as a Strategy for Change: Indonesia's New Village Law. Asian Journal of Law and Society, 4(2), 2017, 447-471. doi:10.1017/als.2017.21

[8] Hans Antlöv, Anna Wetterberg \& Leni Dharmawan, Village Governance, Community Life, and the 2014 Village Law in Indonesia, Bulletin of Indonesian Economic Studies, 52:2, 2016, 161-183

[9] Vel, J., \& Bedner, A., Decentralisation And Village Governance In Indonesia: The Return To The Nagari And The 2014 Village Law, The Journal of Legal Pluralism and Unofficial Law, 2015, Vol. 47, No. 3, 493-507, http://dx.doi.org/10.1080/07329113.2015.110937
[10] Marquette, H. "Finding God or Moral Disengagement in The Fight Against Corruption in Developing Countries? Evidence from India and Nigeria". Public Administration and Development, 32, 2012. 